\title{
Az ápolási dokumentáció hatékony alkalmazásának aspektusai
}

10.14232/actasana.2020.2.22-31

\begin{abstract}
ABSZTRAKT
Az ápolási dokumentáció vezetése az egyik legfontosabb önálló ápolói kompetencia, hiszen a dokumentáció egy olyan információforrás, ami visszajelzést ad az ápolók munkájáról és annak minőségéről is. Egy strukturálisan és tartalmát tekintve jól összeállított ápolási dokumentáció illeszkedik a dokumentációt alkalmazó területek specifikumaihoz, ápolási gyakorlatához, ami nélkülözhetetlen a személyre szabott és biztonságos betegellátás megvalósulásához. Jelen közlemény célja azápolási dokumentáció hatékony alkalmazását befolyásoló tényezők ismertetése. Szakirodalmi áttekintés során ismertetésre kerülnek az ápolási dokumentációval kapcsolatos irányelvek és útmutatások, továbbá azon hibák, amelyek a dokumentáció vezetése során leggyakrabban elöfordulnak. Hazai vonatkozásban az ápolási dokumentáció kutatása - jelentősége ellenére - nem kap kellő prioritást. $\mathrm{Az}$ ápolóképzésben és az ápolási gyakorlatban végbemenő változások szükségessé teszik az ápolási dokumentáció korszerüsítését is.
\end{abstract}

\footnotetext{
ABSTRACT

Documentation of nursing process is one of the most important independent nursing competence because it is an important source of information that provides feedback on the work of nurses and the quality of nursing care. A well-structured nursing documentation reflects the specifics of the different areas in nursing practice, which is essential for the provision of safe and personalized patient care. The aim of the study is to describe the factors that influence the effective use of nursing documentation. Guidelines and rules about nursing documentation are outlined in a literature review, as well as the most common errors and mistakes that occur during documentation. Despite of the importance, research on nursing documentation is not given sufficient priority in domestic context. Changes in nursing education also require the updating of nursing documentation.
}

\section{KULCSSZAVAK}

ápolási folyamat, ápolási

dokumentáció

\section{SZERZÖI INFORMÁCIÓ \\ Oláh Mónika ${ }^{1}$}

${ }^{1}$ Szegedi Tudományegyetem Egészségtudományi és Szociális Képzési Kar Ápolási Tanszék email:

olahmonika@etszk.u-szeged.hu 


\section{Bevezetés}

Az ápolás elsődleges célja, hogy meghatározza a kliens és családja egészségügyi problémáira adott reakcióit, a jóllét szintjét, a segítség iránti igényüket, további célja a kliens és a családja fizikai, érzelmi támogatása, oktatása, irányítása, vezetése a gyógyulási, ápolási folyamaton keresztül (Tulkán, 2009).

$\mathrm{Az}$ ápolási beavatkozások segítik a klienst és a családját szükségleteik kielégítésében, ugyanakkor preventív aspektusúak is. Az ápolási folyamat az a keret, amely segíti az ápolót ezen célok realizálásában. Az ápolással kapcsolatosan korszerünek számító definíció már nem tartalmazza az ápolás függő funkcióját, csak az együttmüködő és önálló tevékenységeket ismeri el, hangsúlyozva az ápoló terapeuta szerepét (ICN, 2010). Az ápolási folyamat mozzanatait az ápolási dokumentáció tartalmazza a helyzetfelméréstől kezdődően a beteg elbocsátásáig. Az ápolási dokumentációnak vissza kell tükröznie azt, hogy ápoló tudatosan és felelősségteljesen vezeti a beteget a gyógyulás útján. Több kutatás is beszámolt arról, hogy a betegek gyógyulása függ az interperszonális kapcsolat minőségétől is (Helembai, 2010). Azon betegek, akik azt érzik, hogy az autonómiájukat tiszteletben tartják, bevonják őket az ápolás folyamatába és partnerként kezelik, eredményesebben gyógyulnak, hiszen motiváltabbak, együttmüködőbbek lesznek. $\mathrm{Az}$ ápolási dokumentáció jelentősége vitathatatlan ebben a folyamatban és vezetése törvényi elöírás is az ápolók számára. Az ápolási dokumentációnak az életmúködéseken túl tartalmaznia kell a betegvezetés mozzanatait is. Napjainkban az ápolás oktatása és gyakorlata olyan átalakuláson megy keresztül, ami szükségessé teszi az ápolási dokumentáció korszerüsítését is a hatékony alkalmazás érdekében. Mind a BSc, mind pedig a kiterjesztett hatáskörü ápolóképzés (APN) elvégzésével az ápolók olyan többletkompetenciákhoz juthatnak a klinikai gyakorlatban, amelyek komplexebb döntéshozási képességeket, kritikus gondolkodást és kooperatív munkavégzést igényelnek. Ezen döntések meghozatalához az ápolóknak információkra van szükségük, a szükséges információk pedig az ápolási dokumentációban kerülnek rögzítésre. Ily módon az ápolási folyamat gondos dokumentációjának, precíz vezetésének jelentősége még inkább hangsúlyossá válik az ápolói munkában a biztonságos betegellátás megvalósulása érdekében.

$\mathrm{Az}$ ápolási dokumentációval kapcsolatos elöírások, valamint a jogi és minőségbiztosítással összefüggő szabályozások útmutatást adnak ahhoz, hogy milyen tartalmi elemeknek kell kötelező jelleggel megjelenni az ápolási dokumentációban (48/2009. (XII.29.) EÜM rendelet). A hatékony alkalmazáshoz azonban az is szükséges, hogy a dokumentáció illeszkedjen az ápoló terapeuta szerepéhez, ezért az intézményeknek a kötelező elemeken túl szakspecifikus tartalommal is ki kell egészíteniük. A szakterülethez illeszkedő dokumentáció az ápolási folyamat valamennyi fázisában segítséget nyújthat az ápolók számára. Számos előnye közül a legfontosabb, hogy informatívabb, részletesebb helyzetfelmérést tesz lehetővé, ami megkönnyíti az egyénre szabott ellátási tervek készítését és az ápolói beavatkozások értékelését is. Egy átgondolt, észszerúen kidolgozott dokumentáció másik előnye, hogy gyorsan kitölthető, csökkentheti az ápolókra nehezedő adminisztrációs terheket, melynek köszönhetően jobban tudnak összpontosítani a szakmai feladatok elvégzésére és több időt tudnak közvetlenül a betegeikkel tölteni. Az ápolási dokumentáció segíthet abban is, hogy az állapotromlásra utaló tünetek időben kerüljenek felismerésre, hiszen követhetőbbé teszi a betegek állapotváltozását és az ápolási beavatkozásokra adott reakcióit (Collins és mtsai., 2013). Az ápolókra nehezedő terhelés olyan hibák kialakulásához vezethet, ami visszafordíthatatlan következményekkel is járhat, és akár halálos kimenetelü is lehet (Ramya és mtsai., 2017). 


\section{Célkitǔzés és módszer}

Jelen közlemény célja az ápolási dokumentáció ápolási folyamatban betöltött szerepének vizsgálata és a hatékony alkalmazást segító és gátló tényezők azonosítása a szakirodalmi áttekintés módszerével. Az irodalomkutatás során multidiszciplináris orvosi adatbázisok, elektronikus folyóiratok és szakkönyvek közleményei kerültek áttekintésre. $\mathrm{Az}$ áttekintés során ismertetésre kerülnek az ápolási dokumentációval kapcsolatos irányelvek és útmutatások, továbbá azon hibák, amelyek a dokumentáció vezetése során leggyakrabban előfordulnak. Az irodalomkutatás során fel kívántam tárni az ápolási dokumentáció jogi oldalról a legfontosabb irányelveket és szabályokat, továbbá olyan közleményeket is kerestem, amelyek a struktúra és tartalom oldaláról mutatják be, hogy miként valósul meg az egyénre szabott ápolási folyamat egyes mozzanatainak dokumentálása a gyakorlatban. $\mathrm{Az}$ ápolási dokumentáció személyi oldaláról cél volt a dokumentáció okozta adminisztratív teher mértékének megállapítása, valamint olyan kutatási beszámolók áttekintése, amelyek az ápolók attitüdjeit, tapasztalatait mutatják be az ápolási dokumentáció alkalmazásával kapcsolatosan..

\section{Az ápolási dokumentáció vezetésével} kapcsolatos ajánlások és irányelvek

$\mathrm{Az}$ irányelvekkel összhangban lévő ápolási dokumentáció megfelel a tényszerüség és a pontosság elvének, továbbá kronologikus sorrendben rögzít minden olyan adatot, ami a beteg gyógykezelésével és ápolásával összefügg (Potter, Perry, 1999). Az evidenciákon alapuló ápolási tervek alkalmazása segíti a betegek szükségleteinek feltárását, az ápolási diagnózisok, célok és beavatkozások fontossági sorrendjének megállapítását, továbbá a biztonságos ellátás személyi feltételeinek azonosítását is. Mindezeken túl lehetővé teszik a betegek állapotváltozásának követését is az ellátás ideje alatt. A NANDA-I, a NIC (Nursing Intervention Classification), a NOC (Nursing Outcomes Classification) és az ICNP (International Classification for Nursing Practice) az ápolási diagnózisoknak, céloknak és beavatkozásoknak átfogó, kutatási eredményeken alapuló, szabványosított osztályozási rendszerei, melyek segítik a döntéshozást, valamint a betegek számára nyújtott ellátás és kezelések kimenetelének leírását (International Nursing Knowledge Association, 2020). Az ANA (American Nurses' Association) által elismert szakszókincsgyüjteményt nemzetközi szinten használják akut ellátást nyújtó intézményekben, járóbeteg szakambulanciákon, krónikus ellátást nyújtó intézményekben és a rehabilitáció során is. A szabványosított osztályozási rendszerek alkalmazása lehetővé teszi az ápolási igények összehasonlítását az intézmények és osztályok között, továbbá segítik az ellátás költséghatékonyságának az értékelését is. Így az intézmények anélkül találhatják meg a költségek csökkentésének lehetőségeit, hogy a betegek biztonsága veszélybe kerülne. További elönyük, hogy a standard szaknyelv használata gyorsabb, pontosabb és hatékonyabb információátadást tesz lehetővé az egészségügyi dolgozók között. Szabványosított osztályozási rendszert használnak Európa több országában is, többek között Ausztriában, Szlovéniában, Svájcban, Németországban, Olaszországban, Andorrában, Izlandon, Norvégiában, Spanyolországban és Portugáliában is (Thoroddsen és mtsai., 2012).

\section{Gyakran előforduló hibák az ápolási folyamat dokumentálása során:}

Napjainkban az ápolók több kihívással néznek szembe, mint valaha. A létszámhiányból adódó nagyfokú leterheltség azt eredményezi, hogy az ápolók kevesebb figyelmet tudnak fordítani a pontos dokumentálásra, így romlik a dokumentáció minősége és ez magában hordozza a hibázás 
lehetőségét is. A következőkben az ápolási folyamat dokumentálása során előforduló leggyakoribb hibák kerülnek ismertetésre. Fontos, hogy az ápolók ismerjék a lehetséges hibákat és tudatosan próbálják ezeket elkerülni, minimalizálni.

1. hibalehetőség: az állapotfelmérés sablonos, hiányos. $\mathrm{Az}$ állapotfelmérés célja egy szisztematikus adatgyüjtés, melynek során a beteg egészségi állapotáról, jóllétéről, panaszairól, tüneteiröl tájékozódunk (Papp K., 2014). A holisztikus betegellátás szemléletének megfelelően fontos, hogy a szomatikus állapot mellett a pszichoszociális tényezők is kerüljenek felmérésre és rögzítésre az ápolási dokumentációban. Ha az ápolás elméletalkotóinak gondolkodását megnézzük, valamennyiük hangsúlyozza az egyéniség, az egyedi válaszreakciók és a kliensben lévő potenciálok elismerésének szerepét az interperszonális kapcsolatokban (Walsh, 1998). Ahhoz, hogy ápolóként eredményesen tudjuk segíteni a beteget a gyógyulás folyamatában, ismernünk kell a megváltozott helyzethez való viszonyulását, az átélt veszteségeit és a megküzdési stratégiáját is (Helembai, 2010). A személyközpontú ápolási filozófia szerint minél jobban megismerjük és megértjük a betegünket, annál hatékonyabb módon tudjuk segíteni a megváltozott helyzethez való alkalmazkodását és a problémaközpontú megküzdési stratégia kialakítását. A részletes, ezen tényezőkre is kiterjedő anamnézis a személyre szabott ápolási terv készítésének az alapja. Ha az állapotfelmérés sablonos és hiányos, nem lehetséges személyre szabott ellátási tervet készíteni a beteg számára. Ilyenkor fennáll annak a veszélye, hogy a szükségletek nem kerülnek feltárásra és az ebből adódó problémák későn kerülnek felismerésre. Az ellátás minőségének javulását eredményezheti, ha a szomatikus ápolási diagnózisok mellett a betegvezetési diagnózisokat is rögzítjük és ezek alapján komplex betegvezetési tervet készítünk a beteg számára.

2. hibalehetőség: hiányoznak az objektív, mérhető adatok a felmérésből és az ápolói dekurzusból. Ahhoz, hogy az ápolási dokumentáció értékes információforrás lehessen, teljesülnie kell a következő elvárásoknak: a dokumentáció legyen világos, tömör, átfogó, hiánytalan, pontos, objektív és időszerü (Goodwin, 2019). Az objektív eredmények dokumentálása azért fontos, mert a pontos, mérhető adatok tényként kezelhetők és megkönnyítik a kitüzött célok értékelését is. A szorongásnak, csökkent önértékelésnek és a tehetetlenségérzésnek is megvannak a meghatározó ismertetőjegyei, amelyeket fontos, hogy a dokumentációban is rögzítsünk.

3. hibalehetóség: az ápolási terv nem kerül revideálásra a beteg állapotváltozásának észlelésekor. A felmérés nem egyszeri alkalom, hanem folyamatos tevékenység az ellátás ideje alatt. A feltárt szükségletek alapján az ápoló a beteggel együttmúködve meghatározza az ápolás célját, a várható eredményeket, valamint a célok elérése érdekében alkalmazott stratégiát (Papp K, 2014). A tervben foglaltak megvalósítását követően az értékelését is együtt végzik. Amennyiben a beteg állapotában változás következik be, az ápolási tervet is módosítani kell. Amennyiben az elkészített ápolási terv nem kerül revideálásra a beteg állapotváltozásának észlelésekor, az ápoló nem tudja bizonyítani, hogy eleget tett annak a feladatának, hogy folyamatos megfigyelés alatt tartotta a betegét.

4. hibalehetőség: a betegellátással kapcsolatos tevékenységek és a gyógyszereléssel kapcsolatos információk rögzítésének elmulasztása. Az ápolási beavatkozásokkal kapcsolatosan a szabályozások előírják a szükséges beavatkozás pontos megnevezését, a végrehajtásidőpontjának rögzítését, valamint a beavatkozáshoz 
kapcsolódó ápolói észlelések dokumentálását is. A szabályozások szerint minden ellátási eseményt annak kell dokumentálni, aki az adott beavatkozást elvégezte, végrehajtotta (48/2009. (XII.29.) EÜM rendelet). Az eredményes együttmüködéshez az is nélkülözhetetlen, hogy az ápoló észlelni tudja a beteg kezelési elöírásokhoz való viszonyulását is. Ha például azt észleljük, hogy egy beteg nem akarja bevenni a számára szükséges gyógyszereket, érdemes időt szánni arra, hogy megismerjük a probléma hátterében meghúzódó okokat a beteg szemszögéből. A beteg félelmeinek, kétségeinek, és a benne élő tévhiteknek a feltárásával csökkenthető a kezelési elöírások elégtelen megvalósulásának a kockázata és segíthetö a terápiás együttmüködés kialakítása.

5. hibalehetőség: gyakori hiba, hogy elmarad a beadott gyógyszer és a gyógyszerre adott válaszreakciók dokumentálása. Ez a hiba különösen veszélyezteti a betegbiztonságot. Fontos, hogy legyen dokumentálva a beadott gyógyszer és a gyógyszerre adott válaszreakció is. Egy amerikai kutatás eredményei szerint az Egyesült Államokban naponta egy haláleset a gyógyszereléssel kapcsolatosan következik be és évente 1,3 millió ember szenved károsodást emiatt (Hayes, 2017).

6. hibalehetőség: a nagyfokú leterheltség miatt csak a müszak végén történik meg a dokumentáció megírása. Az ápolási dokumentációnak pontosan vissza kell tükröznie az ápolási és ellátási események időbeni folyamatát (48/2009. (XII.29.) EÜM rendelet). Az ápolási dokumentáció nem tud jogi védelmet nyújtani az ápolók számára, ha elmarad a betegellátással kapcsolatos tevékenységek rögzítése. A „csak a müszak végén” történő dokumentálás is magában hordozza ezt a veszélyt. Fontos, hogy a dokumentáció kitöltése ne a müszak végén történjen meg, hanem a müszak ideje alatt folyamatosan.
7. hibalehetőség: nincs összhangban az ápolási és az orvosi dokumentáció, kompetencián kívül eső elemek kerülnek rögzítésre az ápolási dokumentációban. Az ápolási dokumentáció vezetésével kapcsolatos irányelvek külön rögzítik a nem önálló funkció alapján történő ápolási beavatkozások dokumentálásával kapcsolatos szabályokat. A jogi védelem tekintetében az is lényeges, hogy az ápolási dokumentáció és az orvosi dokumentáció legyen összhangban egymással, de az ápolási dokumentációban kizárólag az ápolással összefüggő adatok szerepeljenek (Oláh A. és mtsai., 2012).

8. hibalehetőség: duplikálás, ugyanazon adatnak több helyre történő beírása (például ápolási lapra, lázlapra, orvosi betétlapra is). $\mathrm{Az}$ ápolási dokumentáció szerkezetében és tartalmában vissza kell, hogy tükröződjenek az aktuális ellátóterület szakmaspecifikus elemei, a duplikált adatrögzítést azonban kerülni kell. Az ápolók számos ürlapot és formanyomtatványt használnak a munkájuk során. Az ápolási dokumentáció részét képezik a következő adatlapok: ápolási anamnézis, szakápolási felvételi lap, dekurzus lap, lázlap, gyógyszerelő lap, folyadéklap, állapotfelmérő skálák (pl. Norton, Must, Bristol), intenzív megfigyelő lapok és még számos nyomtatvány (Oláh A. és mtsai., 2012). Az adatok duplikált rögzítése is jelenthet veszélyforrást, valamint az adminisztrációs terheket is növeli. A korábbi kutatásaink során azt az eredményt kaptuk, hogy az ápolók úgy érzik, hogy a munkaidő felét a dokumentáció vezetésével töltik (Oláh, 2013). A számos űrlap és formanyomtatvány ellenére sem mondható el sajnos az, hogy az ápolási dokumentációk azt tükröznék vissza, hogy az ápolás egy önálló professzió a maga legitim területeivel. A dokumentáció vezetése többnyire a biomedikális modellnek megfelelően, tevékenységcentrikus módon valósul meg. 
9. hibalehetőség: nehezen olvasható a kézírás, áttekinthetetlen a dokumentáció, a pontos dátumok nem kerülnek rögzítésre. Ha a dokumentáció nehezen áttekinthető, külalakját tekintve rendezetlen, nem tud hatékony információforrásként szolgálni sem az ápolók számára, sem pedig a társszakmák számára. Fontos szabály az is, hogy a dokumentáció lényegre törő és tömör legyen (Halász H., 2015). Az irreleváns, lényegtelen bejegyzések között elveszhetnek a valóban fontos információk. A dokumentáció vezetésével kapcsolatos követelmények szerint a bejegyzéseket pontos dátummal, aláírással is el kell látni. Ezen szabályok betartásával a dokumentáció rendezettebb, áttekinthetőbb lesz, jobban tudja támogatni az ápolói munkát és lehetővé teszi a szakmai felelősség megállapítását is (Lippincott Nursing Education, 2018).

\section{Kritikus vélemények az ápolási doku- mentáció vezetésével kapcsolatosan:}

$\mathrm{Az}$ ápolási dokumentáció vezetésével kapcsolatosan olykor még napjainkban is ellenállás tapasztalható az ápolók részéről. A kritikus vélemények tükrözik az ápolók elvárásait és a fejlesztés szükségességére hívhatják fel a figyelmet.

Az ápolási dokumentációval kapcsolatosan a leggyakoribb kritikák a következők:

- A dokumentáció vezetése időigényes, elveszi az időt a betegellátástól.

- A dokumentáció vezetése felesleges és értelmetlen, mivel nem ezen múlik a beteg gyógyulása.

- A dokumentáció vezetése öncélú, a gyógyítási folyamatot nem támogatja, az orvosok nem használják az ápolási dokumentációt munkájuk során (Oláh, 2013).

$\mathrm{Az}$ ápolói hivatás mindennapos kihívásai, a létszámhiány és az egy före jutó magas betegszám valóban nagyfokú terhet ró az ápolókra (Ramya és mtsai., 2017). Korábbi kutatások szerint az ápolók látják ugyan a dokumentáció előnyeit is (Halász H., 2015), de a feszített munkatempó sokszor ellehetetleníti, hogy maradéktalanul meg tudjanak felelni az aktuális irányelveknek és szabályozásoknak (Oláh és mtsai., 2012).

Az ápolók és az orvosok egymásra utaltsága, a köztük zajló team munka a sikeres gyógyítás érdekében vitathatatlan. Az ápolási dokumentáció elsősorban nem az orvosok számára készül, de a benne rögzített adatok hatékonyabb információátadást tesznek lehetővé, ami segíti az ápolók és orvosok közötti kommunikációt és együttműködést a betegellátás minőségének javulása érdekében. Ahhoz, hogy a munkájuk során más szakmák képviselői is könnyedén tudják használni a dokumentációt, fontos, hogy átfogó, szakmailag korrekt és rendezett legyen.

A kritikus vélemények arra engednek következtetni, hogy az ápolók intuitív módon ráéreznek arra, ami valójában az ápolás lényege, amelyre Hippocrates bölcs intelmével figyelmeztet: „Nem az a legfontosabb, hogy milyen betegsége van valakinek, hanem az, hogy kinek van valamilyen betegsége."

\section{Az elektronikus dokumentáció, mint jövőkép}

Mivel a dokumentációs hibák jelen vannak a gyakorlatban, intézményi szinten fontos megvizsgálni azt, hogy milyen lépéseket lehet tenni az adminisztrációs terhek csökkentése és a hibák elkerülése érdekében. A fejlesztésnek azt a célt kell szolgálnia, hogy az ápolási dokumentáció be tudja tölteni azt a funkcióját a betegellátásban, amiért bevezetésre került. Hazai viszonylatban még nem terjedt el az elektronikus ápolási dokumentáció alkalmazása, de megfontolandó a feltételeinek megteremtése és bevezetése, hiszen azon intézményekben, ahol bevezették, kedvezőek tapasztalatok. Pontosabb, biztonságosabb, időszerübb dokumentációról számolnak be a közlemények, továbbá az ágy mellett vezethető 
elektronikus dokumentáció segítségével a betegek kikérdezése, és az adatrögzítés is lényegesen gyorsabb(Fölker, 2014). Egy kutatás során 100 ápolót kérdeztek meg az elektronikus dokumentációval kapcsolatos tapasztalataikat illetően és 36\% -uk úgy vélte, hogy az elektronikus formában történő dokumentálás csökkentette munkaterhelésüket. A megkérdezett ápolók 75\% -a úgy gondolta, hogy javult a dokumentáció minősége, és 76\% -uk vélte úgy, hogy az elektronikus dokumentáció javítja a betegbiztonságot, a betegek ápolásának minőségét, eredményességét (Moody és mtsai., 2004). Az elektronikus dokumentáció előnyei közé tartozik, hogy teljeskörü dokumentációt tesz lehetővé. A szoftverek a minőségi elöírásoknak megfelelő szabvány nyelv és adatkészlettel rendelkeznek. Az információhoz való jobb hozzáférés javítja a betegekkel kapcsolatosan hozott döntések minőségét (Stokowksi, 2013), hiszen akár tabletről vagy erre szoftveresen felkészített mobiltelefonról is követhetők azok az információk, amelyek a betegmegfigyelő monitorokon is megjelennek. $\mathrm{Az}$ elektronikus dokumentációs szoftverek lehetővé teszik a készletgazdálkodást, a rendelési és leltárfolyamatok áttekintését, az idő és anyagszámlálást is. További praktikus funkció bennük a betegkövetés, valamint az ápolási előzmények értékelése és az előzetes eljárások áttekintése is, ami nagy segítséget jelent a beteg újrafelvételénél, korai kockázatelemzésnél. A technikai feltételeket illetően számos információs és kommunikációs technológia érhető el napjainkban, amelyek képesek az elektronikus dokumentációs szoftverek futtatására és a betegellátás során is hatékonyan alkalmazhatók. Az intézményekben mindenekelőtt teljeskörü, titkosított vezeték nélküli hálózat kiépítése lenne szükséges, de praktikus lehet korszerủ mobilinternettel felszerelt készülékek használata is a mobilitás biztosításához.

A fentiek alapján elmondható, hogy az elektronikus egészségügyi nyilvántartások az egészségügyi környezet igényeinek kielégítésére és fejlesztésére alakultak ki a betegellátás minőségének javulása érdekében. Néhány közlemény beszámol azonban olyan problémákról is, amelyet az ápolók tapasztaltak az elektronikus dokumentáció bevezetését követően. Még azok az ápolók is, akik alapvetően látják az elektronikus dokumentáció előnyeit és a benne rejlő lehetőségeket, ők is észleltek olyan hátrányokat, amelyek negatívan befolyásolhatják a betegek gondozását, ellátását. (Stokowski, 2013). Megemlítették többek között, hogy adódhatnak számítógépekkel kapcsolatos technikai problémák, amelyek akadályozhatják az adatok elektronikus rögzítését. Fontos az is, hogy az ápoló mindig hozzá tudjon férni a számítógéphez amikor eleget kell tennie dokumentációs kötelezettségének. Beszámoltak az ápolók olyan esetekről is, hogy amiatt kellett a müszak végén tovább maradniuk a munkahelyükön, mert napközben nem fértek oda a számítógéphez. Az elektronikus dokumentáció hátrányairól szóló közlemények felhívják a figyelmet a strukturált tartalom veszélyeire is. A korábban rögzített adatok tartalma sok esetben kerül idézésre a dokumentációban, ami nem feltétlenül tükrözi a beteg jelenlegi állapotát (Khuan és mtsai, 2018). Meyerhoefer és munkatársai arról is beszámoltak, hogy az elektronikus dokumentáció bevezetését követően nőtt a betegek elégedetlensége is, mivel zavarta őket, hogy az orvosuk a velük való interakció közben a számítógéppel foglalkozott (Meyerhoefer és mtsai, 2018).

\section{Következtetés}

A szakirodalmi adatok rávilágítanak arra, hogy bár vannak nyilvánvaló előnyei az elektronikus dokumentációnak, a team munka, a betegközpontú ellátás, a betegek biztonsága, betegellátás minőségének egyenlősége, a betegelégedettség, a munkával való elégedettség és nem utolsó sorban a költséghatékonyság nagymértékben a humán faktorok függvényében alakul, amelyből következik 
az a tény is, hogy az ,emberi problémákat technikailag nem lehet megoldani” (Hardin, 1968), így a dokumentáció terén sem.

A hatékony dokumentáció minősége ezért egyrészt az infrastrukturális háttér fejlesztésével növelhető (Fölker, 2014). Ezen túl legalább ekkora hangsúlyt kell helyezni a felhasználó ápolók szemléletének formálására is a képzés során azápolási dokumentáció jelentőségének megértése és a precíz alkalmazás igényének kialakításának érdekében. Aghdam és munkatársai kutatásuk során 120 ápolóhallgató ápolási dokumentációval kapcsolatos tudását, attitüdjét és teljesítményét vizsgálták. A tudásszintre vonatkozó eredményeik szerint a hallgatók többségének átlagos, mérsékelt tudása van a dokumentáció vezetésével kapcsolatosan, mindösszesen a hallgatók 3,3\%-a rendelkezett magas tudásszinttel. A hallgatói attitüdöket vizsgálva azt kapták eredményül, hogy a hallgatók döntő többsége (81\%) egyetért azzal, hogy az ápolási dokumentáció kedvezően befolyásolja az ellátás gyakorlatát és többségük érzi jogi szempontból is a fontosságát. A legkedvezőtlenebbnek bizonyult a hallgatók attitüdje a következő állításokkal kapcsolatosan: azápolóknak inkább a betegellátásra kell összpontosítaniuk a dokumentáció helyett, az ápolási dokumentáció csökkentheti az ápolókra nehezedő munkaterhelést és hogy ápolási dokumentáció értékes forrás lehet az ápolástudományi kutatásokhoz. A tudáson és az attitüdön túl vizsgálták a hallgatók által készített dokumentációk minőségét is és azt az eredményt kapták, hogy a hallgatók törekszenek az olyan alapvető szabályok betartására, mint az áttekinthetőség és olvashatóság, de pontatlanul és hiányosan történik a betegek állapotváltozásának és a gyógyszerre adott válaszának a dokumentálása (Aghdam és mtsai., 2012).

Mindezek alapján elmondható, hogy az ápolási dokumentáció a magas színvonalú, személyközpontú és biztonságos betegellátásban nélkülözhetetlen szerepet tölt be. Az ápolási dokumentáció vezetésének szabályozási, tartalmi és strukturális, valamint a felhasználási terület sajátosságainak feltárása a hiányosságok pótlásán túl olyan ismeretek feltárását teszi lehetővé, amelyek jelentős mértékben hozzájárulhatnak a biztonságos betegellátás támogatásához, a növekvő betegelégedettséghez, a fejlesztést igénylő területek meghatározásához, és javaslatok megfogalmazásához.

\section{Irodalomjegyzék}

Aghdam A.M., Lakdizaji S., Rahmani A., Hassankhani H., Ahmadizadeh A. (2012) Survey of knowledge, attitude and performance of nursing students towards nursing documentation, European Journal of Sicentific Research vol.80, No.2 (2012), pp.191-198

Az ápolási dokumentáció tartalmi elemeinek kötelező minimuma a fekvőbeteg-szakellátást nyújtó egészségügyi intézményekben, 48/2009. (XII. 29.) EüM rendelet, 5. sz. melléklet, Magyar Közlöny (2009. december 29.) 193.szám, pp. 47265-47830

Collins, S. A., Cato, K., Albers, D., Scott, K., Stetson, P. D., Bakken, S., \& Vawdrey, D. K. (2013). Relationship between nursing documentation and patients' mortality. American Journal of Critical Care, 22(4), 306-313. https://doi.org/10.4037/ ajcc 2013426

Fölker J. (2014): A Pécsi Tudományegyetem medikai rendszerének mobil alkalmazása, http:// nws.niif.hu/ncd2014/docs/ehu/063.pdf, hivatkozva: 2020.06.30.

Goodwin D.L. (2019) Documentation skills for nursing students, Nursing Made Incredibly Easy 17(2):16-21. https://doi.org/10.1097/01. NME.0000553096.31950.4b

Halász H. (2015) Az ápolási dokumentáció fejlesztésének lehetősége, IME, 14 (5) 
Hardin G. (1968) The Tragedy of the commons, Science 13 Dec 1968, Vol. 162,(3859),pp. 1243-1248, https://doi.org/10.1126/science.162.3859.1243

Hayes K. Medication error, more than double, [Online] 2017. 01. 24. https://www.aarp.org/health/ drugs-supplements/info-2017/medication-errorsrise-fd.html Hivatkozva: 2020. 01. 06.

Helembai K. (2010) Általános ápoláslélektan, Medicina kiadó, Budapest

International Counsel of Nursing: Nursing Definitions [Online] https://www.icn.ch/nursingpolicy/nursing-definitions Hivatkozva: 2020. 0429.

International Nursing Knowledge Association: NANDA-I NIC NOC for Safe Patient Care, [Online] https://kb.nanda.org/article/AA-00281/0/ NANDA-I-NIC-NOC-for-Safe-Patient-Care.html Hivatkozva: 2020.01.16.

Khuan L., Hanafiah M. J. and N. Makhdzir (2018) Experience of electronic nursing documentation in a hospital setting: A qualitative study, Journal of Nursing Care, Volume 7. https://doi. org/10.4172/10.4172/2167-1168-C4-073

Lippincott Nursing Education (2018) Nursing documentation: How to avoid the most common medical documentation errors, Wolters Kluwer [Online] 2018.02. 22. http://nursingeducation.lww. com Hivatkozva: 2020.04.10.

Meyerhoefer C. D, Sherer S.A., Deily M.E, ShinYi Chou, Xiaohui Guo, Chen J., Sheinberg M., Levick D. (2018) Provider and patient satisfaction with the integration of ambulatory and hospital EHR systems, Journal of the American Medical Informatics Association, Volume 25, Issue 8, August 2018, Pages 1054-1063, https://doi.org/10.1093/ jamia/ocy048
Moody L.E., Slocumb F.E., Berg B. (2004) Electronic Health Documentation in Nursing, Computers, Informatics, Nursing 22(6) https://doi. org/10.1097/00024665-200411000-00009

Oláh A., Németh K., Pálfiné Szabó I., Tulkán I., Jankó A., Fehér R., Zborovján F., Raskovicsné Csernus M.: Kritikus gondolkodás az ápolásban, az ápolás folyamata és dokumentációja, in: szerk: Oláh A, Az Ápolástudomány tankönyve (2012), Medicina Könyvkiadó Zrt., pp. 281-293.

Oláh M (2013) Az ápolási dokumentáció, a vezetésére fordított idő és az adminisztratív tevékenységgel kapcsolatos ápolói attitüdök függvényében, Nővér, 26. évfolyam 5. szám, 24-30

Papp K, Ujváriné. Siket A. (2014) Az egészségügy és az ápolás általános alapelvei, Digitális Tankönyvtár, Debreceni Egyetem Egészségügyi Kar, https://regi.tankonyvtar.hu/hu/tartalom/ tamop412A/2010_0020_apolas_magyar/index.html Letöltve: 2020. 02.21

Potter P.A., Perry A. G (1999) Az ápolás elméleti és gyakorlati alapjai, Medicina Könykiadó Rt., Budapest,

Ramya Krishna, Khyati G.V. (2017) Nursing Errors in Documentation: A Review , RUAS-UAS JMC, 3 (2), [Online] http://www.msruas.ac.in/pdf_files/ Publications/MCJournals/August2017/Paper3.pdf Hivatkozva:2020.04.08.

Stokowski L.A. Electronic nursing documentation: charting new territory, Medscape, [Online] 2013.09.12. Hivatkozva: 2020.04.08. https://www. medscape.com/viewarticle/810573_4

Thoroddsen A., Ehrenberg A, Sermeus W., Saranto K. (2012) A survey of nursing documentation, terminologies and standards in European countries, 
11th International Congress on Nursing Informatics, June 23-27, 2012, Montreal, Canada. in: NI 2012 (2012). 2012 06. 23; 2012:406. eCollection 2012.

Tulkán I. (2009) Az ápolási dokumentáció, in: Dr. Bokor Nándor - Általános ápolás és gondozástan, Medicina Könykiadó Zrt., Budapest,

Walsh, M. (1998) Modellek a klinikai betegápolásban, Medicina Könyvkiadó Rt., Budapest 